Society for the Anthropology of Work • Essential Labor

\title{
There is Nothing \\ Revelatory About It: \\ Racialized Labor in the Age of COVID-19
}

\section{Elana Resnick}

Published on: May 23, 2020

DOI: $10.21428 / 1 \mathrm{~d} 6 \mathrm{be} 30 \mathrm{e} .3 \mathrm{ddbc} 43 \mathrm{c}$

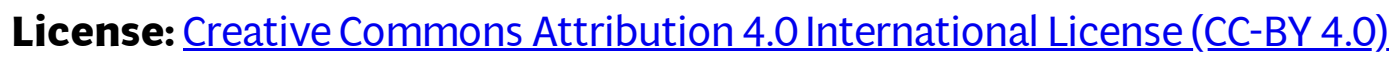


I pulled up Facebook Messenger and called Maria, ${ }^{1}$ a good friend in the urban Bulgarian neighborhood of Fakulteta, soon after reading about the police blockade. Fakulteta is a racially segregated and economically diverse neighborhood and has been so for almost a century. It is the largest Romani neighborhood in Sofia, the sprawling capital of Bulgaria, and a place in which I have spent a great deal of time. When I called, the entrance to Fakulteta was surrounded by police with masks and megaphones ensuring that its residents did not leave. Officials claimed that the blockade would hinder the spread of COVID-19. It was an act of racialized containment in the guise of public health protection.

I asked Maria what she was doing in the midst of everything I was reading about. She shifted the conversation away from the police presence to focus on her household labor and her concern about my own situation, being at home with a baby. She asked if I had enough bleach to make sure that we would be safe. "It's so much work, pouring bleach everywhere, scrubbing, then calling the municipality to come wash the streets," she told me, describing a form of essential labor that she and her neighbors have come to take for granted. She went on: "You need to make sure you have bleach, too. It stings your eyes but you need to use it every day, especially with a small child."

For Maria and her neighbors, the essential labor of cleaning during COVID-19 ties into larger, persistent networks of institutional racism and infrastructural inequity. Their experiences challenge widespread accounts of inequality in the time of COVID-19 that are cast in the language of revealing, exposure, and laying bare. While COVID-19 has had drastically diverging effects rooted in longstanding institutional racism, this fact is a "reveal" only for those who have, until now, had the privilege not to pay attention. For Fakulteta residents, COVID-19 is not revelatory. It is yet another manifestation of the systemic racism that Roma across Europe face in their everyday lives.

Segregated neighborhoods like Fakulteta have been in a state of limited infrastructure access for decades. Tens of thousands of residents lack running water and other socalled public goods, despite having official deeds to their homes. On the few paved streets that connect the neighborhood to the rest of the city there is intermittent waste collection, at best. Any infrastructural repairs that happen are linked with periods of political upheaval. There are, noticeably, only pothole repairs and speed bump installations during the weeks leading up to important elections. 
When a pipe bursts, sometimes the municipality comes to fix it and sometimes it doesn't. When it doesn't, residents group together, rent a bulldozer, and repair it themselves. When the government does not provide adequate access to waste collection or street cleaning or running water for a population that lives, on average, well below the national poverty line, residents-mostly Romani women-ramp up their already prolific use of bleach at home.

With COVID-19 decimating populations across the globe, the virus is being used as $\underline{\text { a }}$ justification for the far right to take hold of a fearful and increasingly anxious public. In Bulgaria, almost as soon as COVID-19 entered its borders, police set up control points around Romani neighborhoods. According to the mayor of Sofia, these checkpoints were designed to "preserve the lives and health of citizens." However, it is clear that the question of who is a citizen to be protected versus a potential vector of contagion is, at its root, a racialized one. Across Europe, where Roma have been historical targets of persecution, they now continue to face some of the most overtly_ racist discrimination in the European Union.

In Bulgaria, the heightened police presence began in mid-March, when the Minister of Health instructed mayoral offices to build checkpoints in neighborhoods populated by Roma, on the assumption that residents would not comply with state restrictions that limited movement. Racist stereotypes abound as Bulgarian officials treat Romani neighborhoods as hotbeds of disease and noncompliance (see also Costache 2020). This racism continues to be perpetuated under the guise of public health as officials quarantine entire Romani neighborhoods in order to "protect" the non-Roma outside of their borders. Such campaigns pointedly ignore systemic issues of anti-Roma racism in Europe, which manifest in the neglect of public service provision, while reinforcing the racialized focus on individuals-as-vectors.

COVID-19 does not expose anything Fakulteta residents do not already know. They have been living amid infrastructural inequality for decades. Fakulteta residents know all too well about the gaps in EU economic development, the Starbucks storefronts that pop up in walking distance of their homes while they still cannot rely on tap water to drink. They know about the dysfunctional neighborhood schools in which students are expected not to graduate and teachers cycle in and out each year. They know about the segregated hospital wards where Romani women are expected to birth their babies alongside "the other Gypsy women."

Maria and her neighbors have become well-versed in the labor it takes to keep the interiors of their homes immaculate while the dirt roads outside remain unpaved and, 
in periods of heavy rain, sometimes strewn with raw sewage. They know that stocking up on bleach is essential not only in the time of a pandemic but every day, because they sanitize their homes daily to compensate for the lack of street cleaning by the municipality.

Despite, and in part due to, not having access to basic infrastructures like steady running water and waste disposal, Roma throughout Bulgaria constantly clean and disinfect their homes in order to supply what public infrastructure lacks. Although neighborhoods like Fakulteta do not have regular street cleaning, their residents are overrepresented in the waste labor sector. Nearly all street sweepers and much of the janitorial staff inside hotels, businesses, and hospitals are Romani women. That means that they work-in predominantly white Bulgarian neighborhoods-to remove other people’s trash from view (Resnick, forthcoming).

Now, the essential labor of Fakulteta residents is intensifying. While portrayed as noncompliant bodies of contagion, residents continue to work hard to sanitize their own homes, compensating for ongoing infrastructural neglect. Those employed as street cleaners keep working outside of their homes as well. Even as nearly everything in Bulgaria is shut down, Romani women are still sweeping public space. They maintain the cleanliness of the urban landscape despite being policed as forces of contagion. As politicians worry about the economic costs of the coronavirus, they neglect the societal costs for those who are seen as internal others, the first to be outcast, bodies to be contained and not protected. This is not novel, revelatory, or a shifting of the status quo. And still it is important to document, as the pandemic shows yet again how anti-Roma racism continues to take on new forms.

\section{Notes}

1. Names have been anonymized.

\section{Author Bio}

Elana Resnick is Assistant Professor in the Department of Anthropology at the University of California, Santa Barbara.

\section{Preview Image}

Courtesy of Gilbert Mercier. 


\section{References}

Costache, Ioanida. 2020. "'Until we are able to gas them like the Nazis, the Roma will infect the nation': Roma and the ethnicization of COVID-19 in Romania." Dor, April 22.

Resnick, Elana. Forthcoming. "The Limits of Resilience: Managing Waste in the Racialized Anthropocene." American Anthropologist. 